\title{
ANALISIS KUALITAS PELAYANAN WEBSITE PEMERINTAHAN PROVINSI
}

(Studi Kasus: Daerah Khusus Ibukota Jakarta dan Daerah Istimewa Yogyakarta )

\section{Heti Mulyani, Ela Kurniati, Siti Yuliyanti}

Sekolah Tinggi Teknologi Indonesia Tanjungpinang

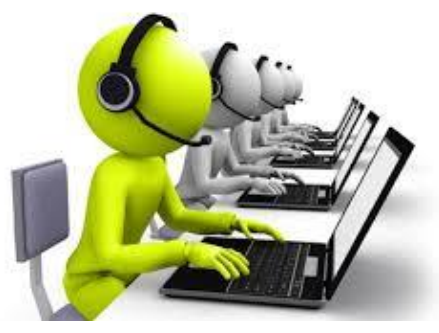

e-mail :heti@sttindonesia.ac.id, siti@sttindonesia.ac.id, ela@sttindonesia.ac.id

\begin{abstract}
Abstrak
Pelayanan publik dalam website merupakan salah satu isu penting dalam penyediaan layanan publik di Indonesia. Salah satunya adalah pelayanan public melalui website.Untuk mengetahui tingkat kualitas website terhadap pelayanan masyarakat dalam berbagai aspek, maka penelitian ini akan membahas analisis kualitas pelayanan pada Website Provinsi DKI Jakarta dan Provinsi DI Yoyakarta dengan menggunakan metode Webqual dengan Importance Performance Analysis(IPA). Pada metode Webqual digunakan parameter dimensi kegunaan, informasi, dan interaksi. Sehingga dapat diukur fasilitas pelayanan website kepada masyarakat dari tingkat kepuasan masyarakat dari dimensi kegunaan, informasi, dan interaksi terhadap masing-masing situs tersebut. Sehingga pelayanan website dapat ditingkatkan sesuai dengan harapan masyarakat DKI Jakarta dan DI Yogyakarta.
\end{abstract}

Kata Kunci : Pelayanan, Webqual, website

\section{PENDAHULUAN}

Pengukuran kualitas website Pemerintah Provinsi yang dianalisis dari segi pelayanan masyarakat merupakan ide dasar dalam penelitian ini. Ide tersebut didasari oleh Instruksi Presiden Nomor 3 tahun 2003 yang menjelaskan bahwa untuk mencapai tata kelola IT Pemerintahan atau E-Government yang baik perlu adanya evaluasi yang kontinu.Pelayanan masyarakat merupakan kegiatan pemerintah yang sesuai dengan peraturan perundang-undangan, oleh karena itu peningkatan pelayanan masyarakat (public service) harus mendapatkan perhatian utama dari pemerintah, karena pelayanan masyarakat merupakan hak-hak sosial dasar dari masyarakat (social rights ataupun fundamental rights). Landasan yuridis pelayanan masyarakat atas hak-hak sosial dasar diatur dalam ketentuan Pasal 18 A ayat (2) dan Pasal 34 ayat (3) UUD 1945 serta Instruksi Presiden No 3 tahun 2003 tentang kebijakan dan strategi nasional pengembangan E-government. Dengan demikian Undang-Undang Dasar mengatur secara tegas tentang pelayanan masyarakat sebagai wujud hak sosial dasar (the rights to receive).Kepuasan masyarakat merupakan salah satu faktor atau ukuran keberhasilan bagi setiap pengembangan dan implementasi sistem informasi pada suatu pemerintahan. Citra kualitas layanan yang baik 
bukanlah berdasarkan sudut pandang atau aktual pihak penyedia layanan, melainkan berdasarkan sudut pandang atau aktual masyarakat. Aktual masyarakat terhadap kualitas layanan merupakan penilaian menyeluruh atas keunggulan suatu layanan.

Upaya menggali aspirasi dari masyarakat sebagai langkah awal dari peningkatan pelayanan masyarakat yang telah berjalan perlu dilakukan salah satunya dengan pengukuran indeks kepuasan masyarakat yang harus terus menerus diteliti sehingga dapat diperoleh informasi untuk meningkatkan pelayanan masyarakat.

Adapun alasan memilih website Pemeritahan Provinsi DKI Jakarta dan Pemerintahan Provinsi DI Yogyakarta yang dianalisis yaitu karena kedua provinsi tersebut memiliki Indeks Pembangunan Manusia (IPM) terbesar di Indonesia, hal tersebut berdasarkan data IPM dari Badan Pusat Statistik (BPS). Hal tersebut dapat dilihat pada Tabel 1. Berdasarkan uraian latar belakang di atas, perumusan masalah dalam penelitian ini adalah:

a. Bagaimana hubungan antara dimensi-dimensi dalam WebQual 4.0 dengan tingkat kualitas website Pemeritahan Provinsi DKI Jakarta dan Provinsi DI Yogyakarta.

b. Dimensi yang manakah dari dimensi-dimensi dalam WebQual 4.0 yang berkontribusi lebih besar dengan tingkat kualitas website Pemerintahan Provinsi DKI Jakarta dan Provinsi DI Yogyakarta dibandingkan dengan dimensi-dimensi yang lain.

c. Berdasarkan hubungan yang diperoleh antara dimensi-dimensi dalam WebQual 4.0 dengan tingkat kualitas website tindakan apa yang harus dilakukan manajemen (rekomendasi) guna meningkatkan kualitas website Pemerintahan Provinsi DKI Jakarta dan Provinsi DI Yogyakarta.

Adapun tujuan dari penelitian ini adalah Menganalisis kualitas pelayanan pada website Pemerintahan Provinsi DKI Jakarta dan Provinsi DI Yogyakarta, menganalisis parameter/dimensi pengukuran tingkat kualitas website agar dapatdiambil tindakan yang harus dilakukan untuk rekomendasi guna meningkatkan kualitas website Pemerintahan Pemeritahan Provinsi DKI Jakarta dan Pemerintahan Provinsi DI Yogyakarta berdasarkan dimensi Kualitas Informasi, Kualitas Interaksi Pelayanan dan Kegunaan website .

\section{KAJIAN PUSTAKA}

\section{A. Kualitas Pelayanan}

Kata kualitas mengandung banyak definisi dan makna karena orang yang berbeda akan mengartikannya secara berlainan, seperti kesesuaian dengan persyaratan atau tuntutan, kecocokan untuk pemakaian perbaikan berkelanjutan, bebas dari kerusakan atau cacat, pemenuhan kebutuhan pelanggan, melakukan segala sesuatu yang membahagiakan. Dalam 
perspektif TQM (Total Quality Management) kualitas dipandang secara luas, yaitu tidak hanya aspek hasil yang ditekankan, tetapi juga meliputi proses, lingkungan dan manusia.Hal ini jelas tampak dalam defenisi yang dirumuskan oleh Goeth dan Davis yang dikutip Tjiptono (2012:51) bahwa kualitas merupakan suatu kondisi dinamis yang berhubungan dengan produk, jasa, manusia, proses, dan lingkungan yang memenuhi atau melebihi harapan.Sebaliknya, definisi kualitas yang bervariasi dari yang kontroversional hingga kepada yang lebih strategik.

Pelayanan dapat didefinisikan sebagai segala bentuk kegiatan/aktifitas yang diberikan oleh satu pihak atau lebih kepada pihak lain yang memiliki hubungan dengan tujuan untuk dapat memberikan kepuasan kepada pihak kedua yang bersangkutan atas barang dan jasa yang diberikan.Pelayanan memiliki pengertian yaitu terdapatnya dua unsur atau kelompok orang dimana masing-masing saling membutuhkan dan memiliki keterkaitan, oleh karena itu peranan dan fungsi yang melekat pada masing-masing unsur tersebut berbeda.Hal-hal yang menyangkut tentang pelayanan yaitu faktor manusia yang melayani, alat atau fasilitas yang digunakan untuk memberikan pelayanan, mekanisme kerja yang digunakan dan bahkan sikap masing-masing orang yang memberi pelayanan dan yang dilayani.

\section{B. Webqual}

Pada penelitian ini digunakan metode webqual 4.0. Webqual merupakan salah satu metode atau teknik pengukuran kualitas website berdasarkan aktual pengguna akhir. Metode ini merupakan pengembangan dari Servqual- yang disusun oleh Parasuraman, yang banyak digunakan sebelumnya pada pengukuran kualitas jasa. Instrumen penelitian pada Webqual tersebut dikembangkan dengan metode Quality Function Development (QFD). Webqual sudah mulai dikembangkan sejak tahun 1998 dan telah mengalami beberapa iterasi dalam penyusunan dimensi dan butir-butir pertanyaannya. Penelitian Barnes dan Vidgen (2003) yang menggunakan Webqual 4.0 untuk mengukur kualitas website yang dikelola oleh OECD (Organization for Economic Cooperation and Development).'

\section{METODE}

\section{A. Pengumpulan Data}

Pengumpulan data dalam penelitian ini menggunakan teknik kuesioner adalah sejumlah pertanyaan tertulis yang digunakan untuk memperoleh informasi dari responden tentang hal-hal yang diketahui atau dilakukan terhadap website .Kuesioner ini dimaksudkan untuk memperoleh informasi secara tertulis dari responden (dikhususkan pada mahasiswa IPB yang berasal dari Provinsi DKI Jakarta dan Provinsi DI Yogyakarta).

\section{B. Analisis Pengolahan Data}


Penelitian dengan metode webqual 4.0 disusun berdasarkan beberapa variabel sebagaimana terlihat pada gambar dibawah :

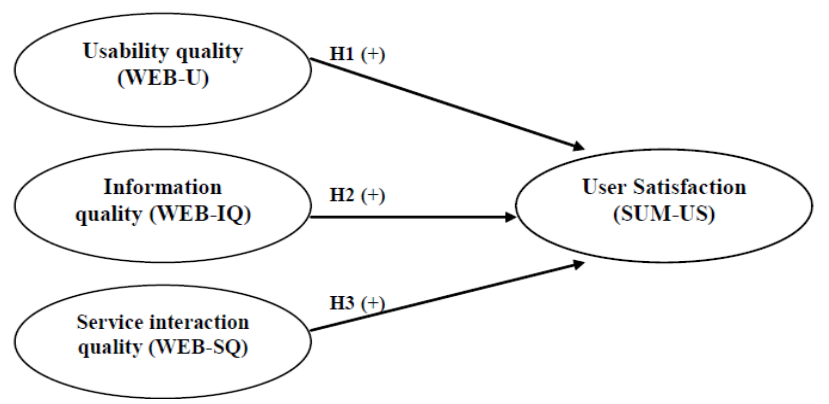

Gambar 1.Conceptual model for user satisfaction using WEBQUAL ${ }^{8}$

Pada penelitian telah ditentukan bahwa untuk dimensi usability quality pertanyaan nomor 1-5, information quality pertanyaan nomor 6-10, service interaction quality pertanyaan nomot 11-15, dan penentuan sampel berdasarkan minimal responden dalam statistic hal ini dikarenakan jika menggunakan perhintungan sampel dari jumlah penduduk DKI Jakarta atau DI Yogyakarta akan terlalu banyak responden.

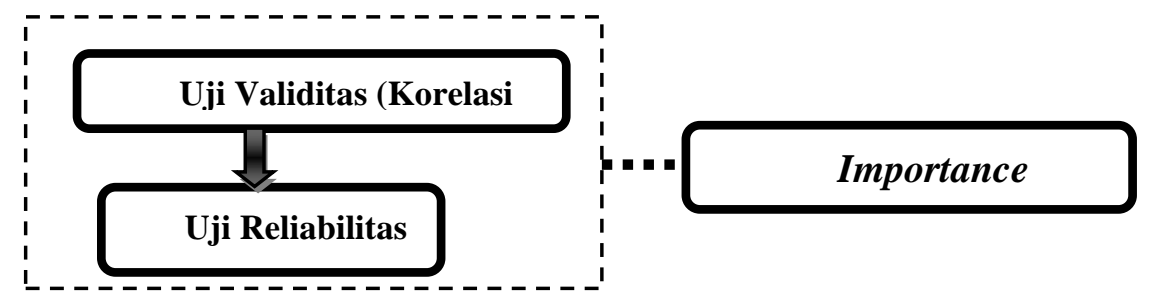

Gambar 2. Tahapan pengolahan Kuesioner dengan Metode Webqual

\section{Analisis Pengujian}

Tahapan pengolahan data kuesioner dengan Metode Webqual:

1. Uji Validitas

Setelah kuesioner selesai disebar dan diperoleh hasilnya, belum berarti kuesioner tersebut dapat langsung digunakan sebagai alat ukur penelitian, perlu uji validitas.Uji validitas menggunakan rumus Uji Korelasi Pearson Product Moment.

$$
\text { rhitung }=\frac{n\left(\sum X Y\right)-\left(\sum X\right)\left(\sum Y\right)}{\sqrt{\left[n \sum X^{2}-\left(\sum X\right)^{2}\right]\left[n \sum Y^{2}-\left(\sum Y\right)^{2}\right]}}
$$


2. Uji reliabilitas

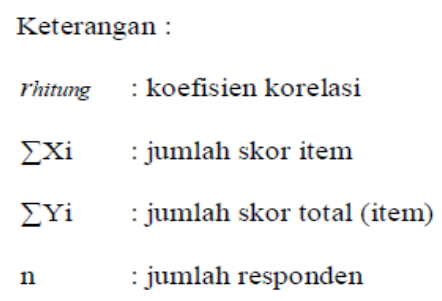

Setelah mengukur validitas maka perlu mengukur reliabilitas data, apakah alat ukur dapat digunakan atau tidak (Hidayat, 2009, p.102). Uji reliabilitas instrumen penelitian ini akan menggunakan reliability analysis dengan teknik Alpha Cronbach yang mempunyai rumus sebagai berikut:

$$
\alpha=\left[\frac{n}{n-1}\right]\left[\frac{S^{2}-\sum_{i=2}^{n} S i^{2}}{S^{2}}\right]
$$

Keterangan:

$\alpha \quad=$ Koefisien reliabilitas instrumen Alpha Cronbach

$\mathrm{n} \quad=$ Jumlah butir pernyataan

$\mathrm{S}^{2} \quad=$ Varian skor secara keseluruhan

Jumlah varian dicari terlebih dahulu dengan cara mencari nilai varian tiap butir dengan persamaan sebagai berikut:

$$
S=\frac{\sum X^{2} \frac{\left(\sum X\right)^{2}}{n}}{n}
$$

Keterangan:

$$
\begin{aligned}
& \mathrm{S}=\text { varian } \\
& \mathrm{X}=\text { nilai skor yang dipilih } \\
& \mathrm{n}=\text { jumlah sampel }
\end{aligned}
$$

Suatu instrumen alat ukur dikatakan reliabel dan bisa diproses pada tahap selanjutnya jika nilai CronbachAlpha > 0,7 (Sekaran, 2006: 182). Jika instrumen alat ukur memiliki nilai CronbachAlpha<0,7 maka alat ukur tersebut tidak reliabel.

\section{Importance Performance Analysis}

Teknik analisis ini pertama kali dikemukakan oleh John A. Martila dan John C. James (1977). Teknik ini merupakan suatu teknik yang membandingkan tingkat harapan pengguna layanan dengan tingkat aktual yang telah ditampilkan atau telah terjadi. Meskipun dalam konsep kepuasan pengguna layanan berkaitan dengan dua faktor, yaitu harapan dan aktual, akan tetapi 
untuk lebih memperjelas konsep, maka faktor harapan (expectation) sering diganti dengan faktor kepentingan pengguna layanan (Freddy Rangkuti, 2006). ${ }^{1}$

Untuk dapat mengukur kualitas website, terlebih dahulu ditentukan variabel-variabel penelitian. Dalam penelitian ini,variabel yang dipakai mengacu pada WebQual yakni alat ukur kualitas yang khusus dirancang untuk mengukur kualitas suatu website. Data dalam penelitian ini diolah dengan menggunakan metode deskriptif kuantitatif. Berdasarkan teknik importanceperformance analysis, maka tingkat kualitas pengguna layana website DKI Jakarta dan DI Yogyakarta ini dihitung dengan membandingkan tingkat kesesuaian antara tingkat harapan/harapan dengan tingkat. Untuk menganalisa tingkat kepentingan pengguna layanan(aktual) dan pengukuran tingkat pelaksanaan(harapan), digunakan skala 4 tingkat (skala Likert) yang dibuat dengan skala degradasi pada jawaban kuesioner sebagaimana tercantum dalam Tabel 1.

Tabel 1. Tabel skala degradasi jawaban kuesioner Aktual dan Harapan

\begin{tabular}{|r|l|l|}
\hline $\begin{array}{c}\text { Bo } \\
\text { bot }\end{array}$ & $\begin{array}{c}\text { Tingkat Kepentingan } \\
\text { Pengguna Layanan (Aktual) }\end{array}$ & $\begin{array}{c}\text { Tingkat Aktual } \\
\text { Pelaksanaan } \\
\text { (Harapan), }\end{array}$ \\
\hline 4 & Sangat setuju & Sangat Penting \\
\hline 3 & Setuju & Penting \\
\hline 2 & Cukup setuju & Cukup Penting \\
\hline 1 & Kurang setuju & Kurang Penting \\
\hline
\end{tabular}

Setelah dilakukan penilaian dari tingkat kepentingan dan tingkat pelaksanaan, maka langkah selanjutnya adalah dilakukan penghitungan tentang tingkat kesesuaian antara kepentingan pengguna

layanan dan aktual situs website milik Pemerintah Provinsi DKI Jakarta dan DI Yogyakarta. "Tingkat kesesuaian adalah hasil perbandingan skor aktual dengan skor kepentingan.Tingkat kesesuaian inilah yang akan menentukan ukuran prioritas peningkatan faktorfaktor yang akan mempengaruhi kepuasana pelanggan" (J. Supranto, 2001:241). Adapun rumus yang digunakan untuk mengukur tingkat kesesuaian ini adalah :

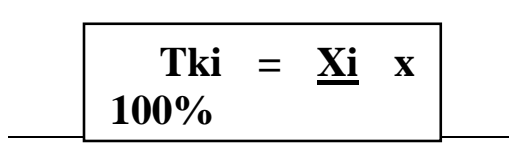


Tki $=$ Tingkat kesesuaian

$\mathrm{Xi}=$ Skor penilaian Aktual website

Yi $=$ Skor penilaian kepentingan pengguna layanan(Harapan) website

Berikut dapat dilihat pada tabel 2.analisis tingkat kesesuaian antara aktual dan harapan dengan model analisis Martil dan James, 1977 dalam Sihombing, 2006².

Tabel 2. Tingkat kesesuaian aktual terhadap aktual tingkat harapan

\begin{tabular}{|c|l|l|}
\hline Bobot & Tingkat Kesesuaian & Kisaran Kesesuaian \\
\hline $80-100 \%$ & Sangat sesuai & Sangat Penting \\
\hline $70-79 \%$ & Sesuai & Penting \\
\hline $60-69 \%$ & Cukup sesuai & Cukup Penting \\
\hline $50-59 \%$ & Kurang sesuai & Kurang Penting \\
\hline
\end{tabular}

(Sumber : Jurnal Hasil Penelitian Umberto Sihombing, 2006)

Dalam rangka penyederhanaan rumus, maka untuk setiap faktor/unsur yang mempengaruhi kepuasan pengguna layanan disederhanakan dengan rumus sebagai berikut :

$$
\begin{aligned}
& \overline{\mathrm{X}}=\frac{\sum \mathrm{X} 1}{\mathrm{n}} \\
& \overline{\mathrm{Y}}=\frac{\sum \mathrm{Yi}}{\mathrm{n}}
\end{aligned}
$$

Keterangan :

$\mathrm{X}=$ rata-rata skor tingkat aktual /pelaksanaan

$\mathrm{Y}=$ rata-rata skor tingkat kepentingan pengguna layanan

$\mathrm{n}=$ jumlah responden

\section{HASIL DAN PEMBAHASAN}

Pada pembahasan ini, akan disajikan hasil pengolahan data kuesioner penelitian. Penyajian hasil olah data angket digunakan untuk menjawab rumusan masalah dalam penelitian, yaitu menganalisis kualitas layanan website, menganalisis peran serta masyarakat terhadap website dan sebgai rekomendasi dalam meningkatkan kualitas website Pemerintahan Provinsi DKI Jakarta dan DI Yogyakarta. 


\section{Uji Validitas}

\subsection{Uji Validitas Aktual}

Tabel 3. Uji Validitas instrumen Aktual Pemerintahan Provinsi DKI Jakarta

\begin{tabular}{|c|c|c|c|}
\hline $\begin{array}{c}\text { Unsur } \\
\text { Pertanyaan }\end{array}$ & $\begin{array}{c}\text { Corrected Item- } \\
\text { Total Correlation }\end{array}$ & $\begin{array}{c}\text { r- } \\
\text { tabel }\end{array}$ & $\begin{array}{c}\text { Krite } \\
\text { ria }\end{array}$ \\
\hline P1 & 0.459 & $\begin{array}{c}0.36 \\
1\end{array}$ & valid \\
\hline P2 & 0.426 & 0.36 & 1 \\
\hline P3 & 0.526 & 0.36 & valid \\
\hline P4 & 0.724 & 0.36 & valid \\
\hline P5 & 0.659 & 0.36 & valid \\
\hline P6 & 0.652 & 0.36 & valid \\
\hline P7 & 0.631 & 0.36 & valid \\
\hline P8 & 0.705 & 0.36 & valid \\
\hline P9 & 0.53 & 0.36 & valid \\
\hline P10 & & 1 & valid \\
\hline P11 & 0.724 & 0.36 & \\
& & 1 & valid \\
\hline & 0.659 & 0.36 & \\
& & & valid \\
\hline
\end{tabular}

Tabel 4. Uji Validitas instrumen Aktual Pemerintahan Provinsi DI Yogyakarta

\begin{tabular}{|c|c|c|c|}
\hline $\begin{array}{c}\text { Unsur } \\
\text { Pertanyaan }\end{array}$ & $\begin{array}{c}\text { Corrected Item- } \\
\text { Total Correlation }\end{array}$ & $\begin{array}{c}\text { r- } \\
\text { tabel }\end{array}$ & $\begin{array}{c}\text { Krite } \\
\text { ria }\end{array}$ \\
\hline P1 & 0.559 & $\begin{array}{c}0.36 \\
1\end{array}$ & valid \\
\hline P2 & 0.732 & $\begin{array}{l}0.36 \\
1\end{array}$ & valid \\
\hline P3 & 0.702 & $\begin{array}{l}0.36 \\
1\end{array}$ & valid \\
\hline P4 & 0.565 & 0.36 & \\
\hline P5 & 0.789 & 0.36 & valid \\
\hline P6 & 0.662 & 0.36 & valid \\
\hline P7 & 0.649 & $\begin{array}{l}1 \\
1\end{array}$ & valid \\
\hline P8 & 0.38 & 0.36 & valid \\
\hline P9 & 0.674 & $\begin{array}{l}1 \\
1\end{array}$ & valid \\
\hline P10 & & 0.36 & valid \\
\hline P11 & 0.763 & 1 & valid \\
\hline & & 0.36 & \\
& & & valid \\
\hline
\end{tabular}




\begin{tabular}{|l|l|l|r|} 
& & 0.36 & \\
P12 & 0.652 & 1 & valid \\
\hline \multirow{2}{*}{ P13 } & 0.631 & 0.36 & \\
& & 1 & valid \\
\hline \multirow{2}{*}{ P14 } & 0.705 & 0.36 & \\
& & 1 & valid \\
\hline P15 & 0.53 & 0.36 & \\
& & 1 & valid \\
\hline
\end{tabular}

\begin{tabular}{|l|l|l|r|} 
& & 0.36 & \\
P12 & 0.439 & 1 & valid \\
\hline P13 & 0.721 & 0.36 & \\
& & 1 & valid \\
\hline \multirow{2}{*}{ P14 } & 0.667 & 0.36 & \\
& & 1 & valid \\
\hline P15 & 0.789 & 0.36 & \\
& & 1 & valid \\
\hline
\end{tabular}

\subsection{Uji Validitas Harapan}

Tabel 5.Uji Validitas instrumen Harapan Pemerintahan Provinsi DKI Jakarta

\begin{tabular}{|c|c|r|r|}
\hline $\begin{array}{c}\text { Unsur } \\
\text { Pertanyaan }\end{array}$ & $\begin{array}{c}\text { Corrected } \\
\text { Item-Total } \\
\text { Correlation }\end{array}$ & $\begin{array}{r}\text { r- } \\
\text { tabel }\end{array}$ & $\begin{array}{c}\text { krite } \\
\text { ria }\end{array}$ \\
\hline P1 & 0.459 & $\begin{array}{r}0 . \\
361\end{array}$ & valid \\
\hline P2 & 0.426 & $\begin{array}{r}0 . \\
\text { P61 }\end{array}$ & valid \\
\hline P3 & 0.526 & 361 & valid \\
\hline P4 & 0.724 & 361 & valid \\
\hline P5 & & 0. & \\
\hline P6 & 0.659 & 361 & valid \\
\hline & 0.652 & 361 & valid \\
\hline
\end{tabular}

Tabel 6. Uji Validitas instrumen Harapan Pemerintahan Provinsi DI Yogyakarta

\begin{tabular}{|c|c|c|c|}
\hline $\begin{array}{c}\text { Unsur } \\
\text { Pertanyaan }\end{array}$ & $\begin{array}{c}\text { Corrected } \\
\text { Item-Total } \\
\text { Correlation }\end{array}$ & $\begin{array}{c}\text { r- } \\
\text { tabel }\end{array}$ & $\begin{array}{c}\text { krite } \\
\text { ria }\end{array}$ \\
\hline P1 & 0.784 & 0.36 & valid \\
\hline P2 & 0.599 & 0.36 & \\
\hline P3 & 0.657 & 1 & valid \\
\hline P4 & 0.392 & 0.36 & \\
& & 1 & valid \\
\hline P5 & 0.789 & 0.36 & \\
\hline P6 & & 1 & valid \\
\hline & 0.607 & 0.36 & \\
\hline
\end{tabular}




\begin{tabular}{|c|c|c|c|}
\hline P7 & 0.631 & $\begin{array}{r}0 . \\
361\end{array}$ & valid \\
\hline P8 & 0.705 & $\begin{array}{r}0 . \\
361 \\
\end{array}$ & valid \\
\hline P9 & 0.53 & $\begin{array}{r}0 . \\
361 \\
\end{array}$ & valid \\
\hline P10 & 0.724 & $\begin{array}{r}0 . \\
361\end{array}$ & valid \\
\hline P11 & 0.659 & $\begin{array}{r}0 . \\
361 \\
\end{array}$ & valid \\
\hline $\mathrm{P} 12$ & 0.652 & $\begin{array}{r}0 . \\
361 \\
\end{array}$ & valid \\
\hline P13 & 0.631 & $\begin{array}{r}0 . \\
361\end{array}$ & valid \\
\hline P14 & 0.705 & $\begin{array}{r}0 . \\
361\end{array}$ & valid \\
\hline P15 & 0.53 & $\begin{array}{r}0 . \\
361 \\
\end{array}$ & valid \\
\hline
\end{tabular}

\begin{tabular}{|c|c|c|c|}
\hline P7 & 0.417 & $\begin{array}{l}0.36 \\
1\end{array}$ & valid \\
\hline P8 & 0.472 & $\begin{array}{l}0.36 \\
1\end{array}$ & valid \\
\hline P9 & 0.495 & $\begin{array}{l}0.36 \\
1\end{array}$ & valid \\
\hline P10 & 0.607 & $\begin{array}{l}0.36 \\
1\end{array}$ & valid \\
\hline P11 & 0.769 & $\begin{array}{l}0.36 \\
1\end{array}$ & valid \\
\hline P12 & 0.646 & $\begin{array}{l}0.36 \\
1\end{array}$ & valid \\
\hline P13 & 0.657 & $\begin{array}{l}0.36 \\
1\end{array}$ & valid \\
\hline P14 & 0.424 & $\begin{array}{l}0.36 \\
1\end{array}$ & valid \\
\hline P15 & 0.533 & $\begin{array}{l}0.36 \\
1\end{array}$ & valid \\
\hline
\end{tabular}

\section{Uji Reliabilitas}

2.1 Uji Reliabilitas Aktual 


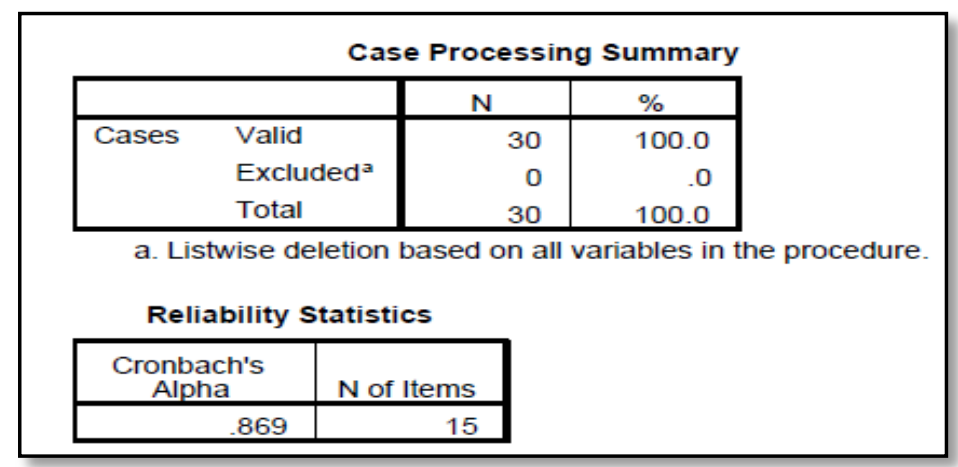

Gambar 3.Uji Reliabilitas Aktual DKI Jakarta

3.2 Uji Reliabilitas Harapan

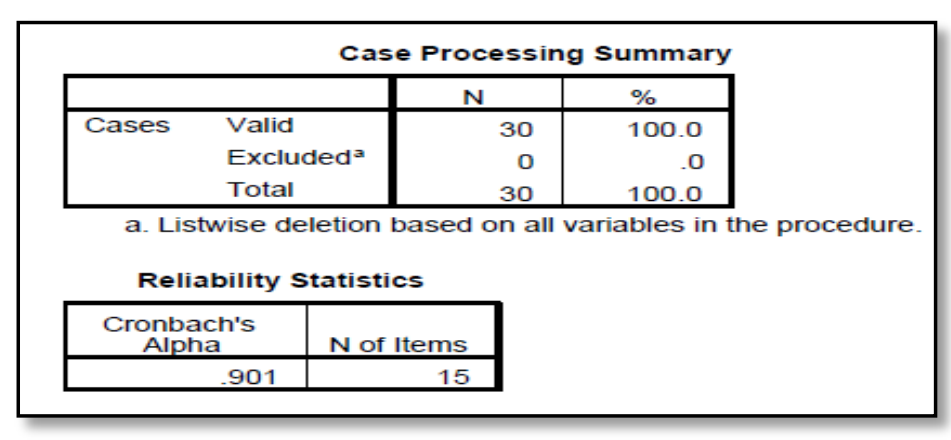

Gambar 5.Uji Reliabilitas Harapan DKI Jakarta

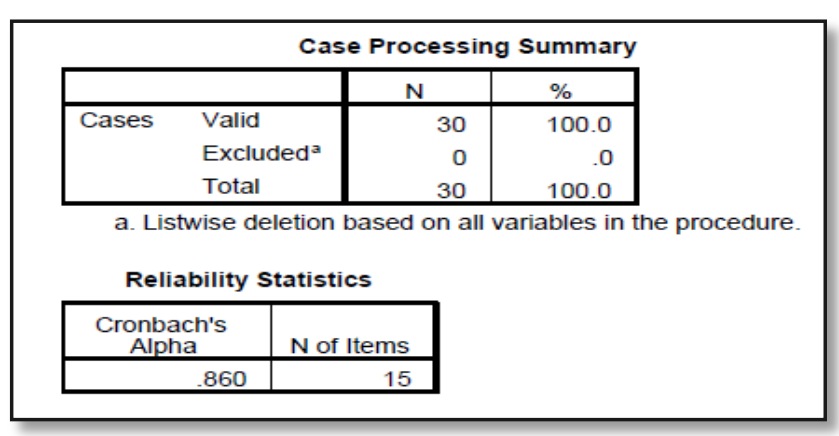

Gambar 4.Uji Reliabilitas Aktual DI Yogyakarta

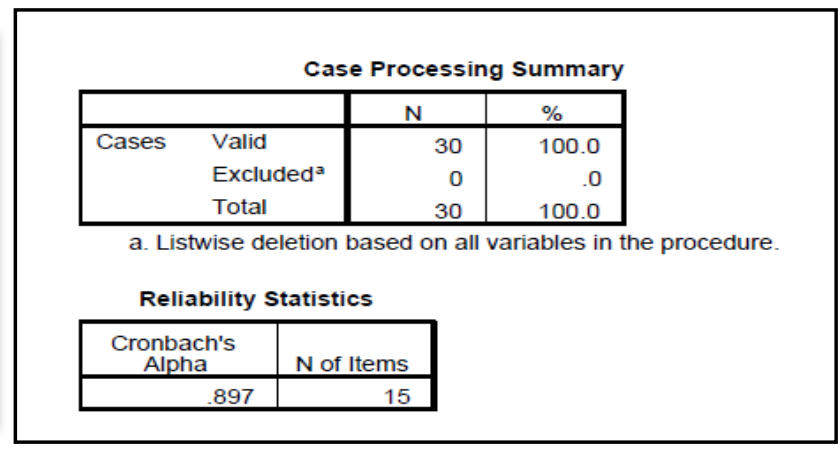

Gambar 6. Uji Reliabilitas Harapan DI Yogyakarta

\section{Analisis Tingkat Kesesuaian Antara harapan dengan Aktual Layanan website}

Bagian ini akan menghitung seberapa besar tingkat kesesuaian antara aktual dan harapan terhadap unsur kualitas pelayanan website Pemerintahan Provinsi DKI Jakarta dan DI Yogyakarta. Tetapi terlebih dahulu akan menampilkan skala hasil penilaian pengguna layanan aktual dan harapan. 
Tabel 7. Kesesuaian antara harapan dan aktual layanan website Pemerintahan Provinsi DKI Jakarta

\begin{tabular}{|c|c|c|c|c|c|c|c|c|c|c|c|}
\hline \multirow{3}{*}{$\begin{array}{l}\mathbf{N} \\
\mathbf{0}\end{array}$} & \multirow{3}{*}{ Unsur Pertanyaan } & \multicolumn{10}{|c|}{ Skala Pengukuran } \\
\hline & & \multicolumn{5}{|c|}{ AKTUAL } & \multicolumn{5}{|c|}{ HARAPAN } \\
\hline & & 4 & 3 & 2 & 1 & $\begin{array}{c}\text { Tota } \\
1\end{array}$ & 4 & 3 & 2 & 1 & Total \\
\hline 1 & Apakah tampilan situs jakarta.go.id menarik? & 0 & 7 & 15 & 8 & 59 & 0 & 29 & 1 & 0 & 89 \\
\hline 2 & Apakah situs tersebut mudah dijelajahi ? & 14 & 11 & 5 & 0 & 152 & 8 & 16 & 6 & 0 & 470 \\
\hline 3 & Apakah Interaksi dengan situs jelas? & 6 & 10 & 12 & 2 & 254 & 8 & 15 & 7 & 0 & 346 \\
\hline 4 & Apakah website jakarta.go.id tersebut mudah dioperasikan? & 9 & 16 & 0 & 5 & 224 & 2 & 24 & 4 & 0 & 404 \\
\hline 5 & $\begin{array}{l}\text { Apakah anda pernah menggunakan fasilitas yang disediakan oleh } \\
\text { website jakarta.go.id? }\end{array}$ & 0 & 5 & 2 & 19 & 175 & 1 & 14 & $\begin{array}{l}1 \\
1\end{array}$ & 0 & 382 \\
\hline 6 & $\begin{array}{l}\text { Apakah ada respon terhadap pengaduan yang anda lakukan pada } \\
\text { website jakarta.go.id? }\end{array}$ & 5 & 1 & 5 & 14 & 281 & 13 & 6 & 6 & 0 & 163 \\
\hline 7 & Apakah Layanan yang diberikan sesuai dengan yang dijanjikan? & 5 & 1 & 4 & 14 & 242 & 6 & 14 & 4 & 0 & 186 \\
\hline 8 & Apakah Informasi yang disediakan up to date? & 6 & 12 & 5 & 0 & 62 & 7 & 10 & 6 & 0 & 206 \\
\hline 9 & Apakah Informasi yang disediakan mudah dimengerti ? & 4 & 12 & 4 & 2 & 188 & 5 & 9 & 8 & 0 & 173 \\
\hline 10 & Apakah informasi yang disediakan cukup terperinci ? & 4 & 7 & 9 & 1 & 138 & 2 & 16 & 3 & 0 & 178 \\
\hline 11 & Apakah informasi yang tersedia akurat? & 2 & 11 & 6 & 1 & 140 & 1 & 11 & 8 & 0 & 202 \\
\hline 12 & $\begin{array}{l}\text { Apakah mudah untuk berkomunikasi dengan organisasi (misal: link } \\
\text { web SKPD lain)? }\end{array}$ & 4 & 6 & 6 & 3 & 113 & 13 & 4 & 2 & 0 & 73 \\
\hline 13 & Apakah informasi yang bersifat pribadi diperhatikan dengan seksama? & 3 & 5 & 7 & 3 & 93 & 5 & 10 & 3 & 0 & 111 \\
\hline 14 & $\begin{array}{l}\text { Apakah Situs menyediakan rasa aman ketika pengguna melakukan } \\
\text { transaksi ? }\end{array}$ & 4 & 5 & 5 & 3 & 81 & 6 & 7 & 4 & 0 & 112 \\
\hline 15 & $\begin{array}{l}\text { Menurut anda, bagaimana kualitas pelayanan masyarakat pada } \\
\text { website jakarta.go.id tersebut? }\end{array}$ & 0 & 6 & 3 & 1 & 48 & 0 & 6 & 5 & 0 & 62 \\
\hline
\end{tabular}




\begin{tabular}{|c|c|c|c|c|c|c|c|c|c|c|c|}
\hline \multirow{4}{*}{ No } & \multicolumn{11}{|c|}{\begin{tabular}{c|c|c|c|c|c|c|c|} 
TOTAL & 66 & 5 & 88 & 76 & 2250 & 77 & 1 \\
\end{tabular}} \\
\hline & \multirow{3}{*}{ Unsur Pertanyaan } & \multicolumn{10}{|c|}{ Skala Pengukuran } \\
\hline & & \multicolumn{5}{|c|}{ AKTUAL } & \multicolumn{5}{|c|}{ HARAPAN } \\
\hline & & 4 & 3 & 2 & 1 & Total & 4 & 3 & 2 & 1 & Total \\
\hline 1 & Apakah tampilan situs jogjaprov.go.id menarik? & 0 & 8 & 12 & 10 & 58 & 13 & 13 & 4 & 0 & 99 \\
\hline 2 & Apakah situs tersebut mudah dijelajahi? & 4 & 10 & 13 & 3 & 75 & 16 & 7 & 7 & 0 & 99 \\
\hline 3 & Apakah Interaksi dengan situs jelas? & 5 & 12 & 13 & 0 & 82 & 8 & 17 & 5 & 0 & 93 \\
\hline 4 & Apakah website jogjaprov.go.id tersebut mudah dioperasikan? & 9 & 16 & 2 & 3 & 91 & 12 & 11 & 7 & 0 & 95 \\
\hline 5 & $\begin{array}{l}\text { Apakah anda pernah menggunakan fasilitas yang disediakan oleh website } \\
\text { jogjaprov.go.id? }\end{array}$ & 0 & 5 & 2 & 23 & 42 & 10 & 18 & 2 & 0 & 98 \\
\hline 6 & $\begin{array}{l}\text { Apakah ada respon terhadap pengaduan yang anda lakukan pada website } \\
\text { jogjaprov.go.id? }\end{array}$ & 3 & 6 & 4 & 17 & 55 & 13 & 11 & 6 & 0 & 97 \\
\hline 7 & Apakah Layanan yang diberikan sesuai dengan yang dijanjikan? & 4 & 10 & 15 & 1 & 77 & 4 & 11 & 15 & 0 & 79 \\
\hline 8 & Apakah Informasi yang disediakan up to date? & 8 & 16 & 6 & 0 & 92 & 9 & 15 & 6 & 0 & 93 \\
\hline 9 & Apakah Informasi yang disediakan mudah dimengerti ? & 9 & 16 & 2 & 3 & 91 & 10 & 18 & 2 & 0 & 98 \\
\hline 10 & Apakah informasi yang disediakan cukup terperinci? & 5 & 6 & 18 & 1 & 75 & 6 & 10 & 14 & 0 & 82 \\
\hline 11 & Apakah informasi yang tersedia akurat? & 4 & 10 & 14 & 2 & 76 & 11 & 17 & 2 & 0 & 99 \\
\hline 12 & $\begin{array}{l}\text { Apakah mudah untuk berkomunikasi dengan organisasi (misal: link web } \\
\text { SKPD lain)? }\end{array}$ & 1 & 10 & 15 & 4 & 68 & 8 & 17 & 5 & 0 & 93 \\
\hline 13 & Apakah informasi yang bersifat pribadi diperhatikan dengan seksama? & 7 & 8 & 8 & 7 & 75 & 13 & 11 & 6 & 0 & 97 \\
\hline 14 & $\begin{array}{l}\text { Apakah Situs menyediakan rasa aman ketika pengguna melakukan transaksi } \\
\text { ? }\end{array}$ & 4 & 15 & 8 & 3 & 80 & 13 & 13 & 4 & 0 & 99 \\
\hline
\end{tabular}


15 Menurut anda, bagaimana kualitas pelayanan masyarakat pada website jogjaprov.go.id tersebut?

TOTAL

\begin{tabular}{|r|r|r|r|r|r|r|r|r|r|}
6 & 9 & 13 & 2 & 79 & 16 & 7 & 7 & 0 & 99 \\
\hline 69 & $\mathbf{1 5 7}$ & $\mathbf{1 4 5}$ & $\mathbf{7 9}$ & $\mathbf{1 1 1 6}$ & $\mathbf{1 6 2}$ & $\mathbf{1 9 6}$ & $\mathbf{9 2}$ & $\mathbf{0}$ & $\mathbf{1 4 2 0}$ \\
\hline
\end{tabular}

\section{Analisis Kesesuaian Harapan Dan Aktual Pelayanan Website Pemerintah Provinsi DKI Jakarta dan DI Yogyakarta}

Hasil nilai masing-masing skala pengukuran aktual dan harapan responden dapat dibuat urutan atau peringkat dari unsur-unsur mana sajakah yang menjadi unsur dengan tingkat kesesuaian terendah sampai unsur dengan tingkat kesesuaian yang tertinggi. Tingkat kesesuaian inilah yang akan menentukan urutan peningkatan prioritas dari unsur yang mempengaruhi kepuasan pengguna layanan website .

Tabel 8. Tingkat Kesesuaian Unsur Layanan website Pemerintahan Provinsi DKI Jakarta

\begin{tabular}{|c|c|c|c|c|}
\hline \multirow{2}{*}{$\begin{array}{l}\mathbf{N} \\
\mathbf{0}\end{array}$} & \multirow{2}{*}{$\mathbf{P}$} & \multicolumn{2}{|c|}{$\begin{array}{c}\text { Rata-rata Tingkat } \\
\text { Kepuasan }\end{array}$} & \multirow{2}{*}{$\begin{array}{c}\text { Tingkat } \\
\text { Kesesuaian( } \\
\text { Aktual/ } \\
\text { Harapan) } \\
\text { x100 [\%] }\end{array}$} \\
\hline & & $\begin{array}{l}\text { Penilaian } \\
\text { Aktual(X) }\end{array}$ & $\begin{array}{c}\text { Penilaian } \\
\text { Harapan(Y) }\end{array}$ & \\
\hline 1 & P1 & 59 & 89 & 66.29 \\
\hline 2 & P2 & 152 & 470 & 32.34 \\
\hline 3 & P3 & 254 & 346 & 73.41 \\
\hline 4 & $\mathrm{P} 4$ & 224 & 404 & 55.45 \\
\hline 5 & P5 & 175 & 382 & 45.81 \\
\hline 6 & P6 & 281 & 163 & 172.39 \\
\hline 7 & P7 & 242 & 186 & 130.11 \\
\hline 8 & P8 & 62 & 206 & 30.10 \\
\hline 9 & P9 & 188 & 173 & 108.67 \\
\hline 10 & P10 & 138 & 178 & 77.53 \\
\hline 11 & $\mathrm{P} 11$ & 140 & 202 & 69.31 \\
\hline
\end{tabular}

Tabel 9. Tingkat Kesesuaian Unsur Layanan website Pemerintahan Provinsi DI Yogyakarta

\begin{tabular}{|c|c|c|c|c|}
\hline \multirow{2}{*}{$\begin{array}{l}\mathbf{N} \\
\mathbf{0}\end{array}$} & \multirow{2}{*}{$\mathbf{P}$} & \multicolumn{2}{|c|}{$\begin{array}{c}\text { Rata-rata Tingkat } \\
\text { Kepuasan }\end{array}$} & \multirow{2}{*}{$\begin{array}{c}\text { Tingkat } \\
\text { Kesesuaian } \\
\text { (Harapan/ } \\
\text { Aktual ) } \\
\text { x100[\%] }\end{array}$} \\
\hline & & $\begin{array}{c}\text { Penilaian } \\
\text { Aktual(X) }\end{array}$ & $\begin{array}{c}\text { Penilaian } \\
\text { Harapan(Y) }\end{array}$ & \\
\hline 1 & P1 & 58 & 99 & 58.59 \\
\hline 2 & $\mathrm{P} 2$ & 75 & 99 & 75.76 \\
\hline 3 & P3 & 82 & 93 & 88.17 \\
\hline 4 & $\mathrm{P} 4$ & 91 & 95 & 95.79 \\
\hline 5 & P5 & 42 & 98 & 42.86 \\
\hline 6 & P6 & 55 & 97 & 56.70 \\
\hline 7 & P7 & 77 & 79 & 97.47 \\
\hline 8 & P8 & 92 & 93 & 98.92 \\
\hline 9 & P9 & 91 & 98 & 92.86 \\
\hline 10 & P10 & 75 & 82 & 91.46 \\
\hline 11 & P11 & 76 & 99 & 76.77 \\
\hline
\end{tabular}




\begin{tabular}{|r|c|r|r|r|}
$\mathbf{1 2}$ & P12 & 113 & 73 & 154.79 \\
\hline $\mathbf{1 3}$ & P13 & 93 & 111 & 83.78 \\
\hline $\mathbf{1 4}$ & P14 & 81 & 112 & 72.32 \\
\hline $\mathbf{1 5}$ & P15 & 48 & 62 & 77.42 \\
\hline & & & & \\
RATA-RATA & $\mathbf{1 5 0}$ & $\mathbf{2 1 0 . 4 7}$ & $\mathbf{8 3 . 3 1}$ \\
\hline
\end{tabular}

\begin{tabular}{|r|r|r|r|r|}
$\mathbf{1 2}$ & P12 & 68 & 93 & 73.12 \\
\hline $\mathbf{1 3}$ & P13 & 75 & 97 & 77.32 \\
\hline $\mathbf{1 4}$ & P14 & 80 & 99 & 80.81 \\
\hline $\mathbf{1 5}$ & P15 & 79 & 99 & 79.80 \\
\hline \multicolumn{2}{|c|}{$\begin{array}{c}\text { RATA- } \\
\text { RATA }\end{array}$} & 1116 & 1420 & 79.09 \\
\hline
\end{tabular}

\section{Analisis Tingkat Kualitas Layanan website}

Selanjutnya setelah diketahui tingkat kesesuaian antara aktual aktual dengan harapan dari masing-masing unsur dalam layanan website, maka langkah berikutnya adalah menghitung nilai rata-rata dari penilaian aktual dan harapan pada masing-masing unsur layanan website . Tabel berikut menyajikan perhitungan rata-rata penilaian aktual dan harapan berdasarkan urutan tingkat kesesuaian yang terkecil.

Tabel 10. Perhitungan Rata-rata Kesesuaian Penilaian Aktual dan harapan unsur dalam layanan website Pemerintahan Provinsi DKI Jakarta

\begin{tabular}{|c|c|c|c|c|c|}
\hline $\begin{array}{l}\mathbf{N} \\
\mathbf{0}\end{array}$ & $\begin{array}{c}\text { Unsur } \\
\text { Pertanyaa } \\
\text { n }\end{array}$ & $\begin{array}{c}\text { Penilaia } \\
\text { n Aktual } \\
\text { (X) }\end{array}$ & $\begin{array}{c}\text { Penilaian } \\
\text { Harapan(X } \\
\text { ) }\end{array}$ & $\mathbf{X}$ & $\mathbf{Y}$ \\
\hline 1 & P1 & 59 & 89 & $\begin{array}{r}1.9 \\
7 \\
\end{array}$ & 2.97 \\
\hline 2 & P2 & 152 & 470 & $\begin{array}{r}5.0 \\
7\end{array}$ & 15.67 \\
\hline 3 & P3 & 254 & 346 & $\begin{array}{r}8.4 \\
7\end{array}$ & 11.53 \\
\hline 4 & $\mathrm{P} 4$ & 224 & 404 & $\begin{array}{r}7.4 \\
7 \\
\end{array}$ & 13.47 \\
\hline 5 & P5 & 175 & 382 & $\begin{array}{r}5.8 \\
3\end{array}$ & 12.73 \\
\hline 6 & P6 & 281 & 163 & $\begin{array}{r}9.3 \\
7\end{array}$ & 5.43 \\
\hline
\end{tabular}

Tabel 11. Perhitungan Rata-rata Kesesuaian Penilaian Aktual dan harapan unsur dalam layanan website Pemerintahan Provinsi DI Yogyakarta

\begin{tabular}{|c|c|c|c|c|c|}
\hline No & $\begin{array}{c}\text { Unsur } \\
\text { Pertanyaa } \\
\text { n }\end{array}$ & $\begin{array}{c}\text { Penilaian } \\
\text { Aktual } \\
(\mathbf{X})\end{array}$ & $\begin{array}{c}\text { Penilaian } \\
\text { Harapan(Y } \\
\text { ) }\end{array}$ & $\mathbf{X}$ & $\mathbf{Y}$ \\
\hline 1 & P1 & 58 & 99 & $\begin{array}{r}1.9 \\
3\end{array}$ & 3.30 \\
\hline 2 & $\mathrm{P} 2$ & 75 & 99 & $\begin{array}{r}2.5 \\
0 \\
\end{array}$ & 3.30 \\
\hline 3 & P3 & 82 & 93 & $\begin{array}{r}2.7 \\
3 \\
\end{array}$ & 3.10 \\
\hline 4 & P4 & 91 & 95 & $\begin{array}{r}3.0 \\
3 \\
\end{array}$ & 3.17 \\
\hline 5 & P5 & 42 & 98 & $\begin{array}{r}1.4 \\
0\end{array}$ & 3.27 \\
\hline 6 & P6 & 55 & 95 & $\begin{array}{r}1.8 \\
3\end{array}$ & 3.17 \\
\hline
\end{tabular}




\begin{tabular}{|c|c|c|c|c|c|}
\hline 7 & P7 & 242 & 186 & $\begin{array}{r}8.0 \\
7 \\
\end{array}$ & 6.20 \\
\hline 8 & P8 & 62 & 206 & $\begin{array}{r}2.0 \\
7 \\
\end{array}$ & 6.87 \\
\hline 9 & P9 & 188 & 173 & $\begin{array}{r}6.2 \\
7 \\
\end{array}$ & 5.77 \\
\hline 10 & P10 & 138 & 178 & $\begin{array}{r}4.6 \\
0\end{array}$ & 5.93 \\
\hline 11 & P11 & 140 & 202 & $\begin{array}{r}4.6 \\
7\end{array}$ & 6.73 \\
\hline 12 & P12 & 113 & 73 & $\begin{array}{r}3.7 \\
7 \\
\end{array}$ & 2.43 \\
\hline 13 & P13 & 93 & 111 & $\begin{array}{r}3.1 \\
0\end{array}$ & 3.70 \\
\hline 14 & P14 & 81 & 112 & $\begin{array}{r}2.7 \\
0 \\
\end{array}$ & 3.73 \\
\hline 15 & P15 & 48 & 62 & $\begin{array}{r}1.6 \\
0 \\
\end{array}$ & 2.07 \\
\hline \multicolumn{2}{|c|}{ RATA-RATA } & 150 & 210.47 & $\begin{array}{c}5.0 \\
0\end{array}$ & 7.02 \\
\hline
\end{tabular}

\begin{tabular}{|c|c|c|c|c|c|}
\hline 7 & P7 & 77 & 79 & $\begin{array}{r}2.5 \\
7\end{array}$ & 2.63 \\
\hline 8 & P8 & 92 & 93 & $\begin{array}{r}3.0 \\
7\end{array}$ & 3.10 \\
\hline 9 & P9 & 91 & 98 & $\begin{array}{r}3.0 \\
3\end{array}$ & 3.27 \\
\hline 10 & P10 & 75 & 82 & $\begin{array}{r}2.5 \\
0 \\
\end{array}$ & 2.73 \\
\hline 11 & P11 & 76 & 99 & $\begin{array}{r}2.5 \\
3 \\
\end{array}$ & 3.30 \\
\hline 12 & P12 & 68 & 93 & $\begin{array}{r}2.2 \\
7\end{array}$ & 3.10 \\
\hline 13 & P13 & 75 & 97 & $\begin{array}{r}2.5 \\
0 \\
\end{array}$ & 3.23 \\
\hline 14 & P14 & 80 & 99 & $\begin{array}{r}2.6 \\
7 \\
\end{array}$ & 3.30 \\
\hline 15 & P15 & 79 & 99 & $\begin{array}{r}2.6 \\
3 \\
\end{array}$ & 3.30 \\
\hline \multicolumn{2}{|c|}{ RATA-RATA } & 74.40 & 94.53 & $\begin{array}{c}2.4 \\
8\end{array}$ & 3.15 \\
\hline
\end{tabular}

Pada tabel diatas dapat diketahui perhitungan rata-rata dari penilaian aktual dan harapan pengguna layanan e-Government pada masingmasing unsur layanan. Kualitas pelayanan dapat diketahui dari perbandingan antara harapan dan aktual pelanggan. Apabila aktual pada saat menerima layanan lebih besar atau sama dengan harapan sama maka pengguna menilai pelayanan website milik Pemerintahan Provinsi DKI Jakarta dan DI Yogyakarta berkualitas. Berikut ini tabel yang menyajikan rata-rata tingkat aktual dan harapan untuk menilai kualitas pelayanan website kedua Provinsi tersebut

Tabel 13. Rata-rata Total Tingkat Kepuasan Aktual dan Harapan

\begin{tabular}{|c|c|c|c|}
\hline N & Pertanyaa & $\begin{array}{c}\text { Rata-rata Tingkat Kualitas Website } \\
\text { Pemerintahan Provinsi DKI JAKARTA }\end{array}$ & $\begin{array}{c}\text { Rata-rata Tingkat Kualitas Website } \\
\text { Pemerintahan Provinsi DI }\end{array}$ \\
\hline
\end{tabular}




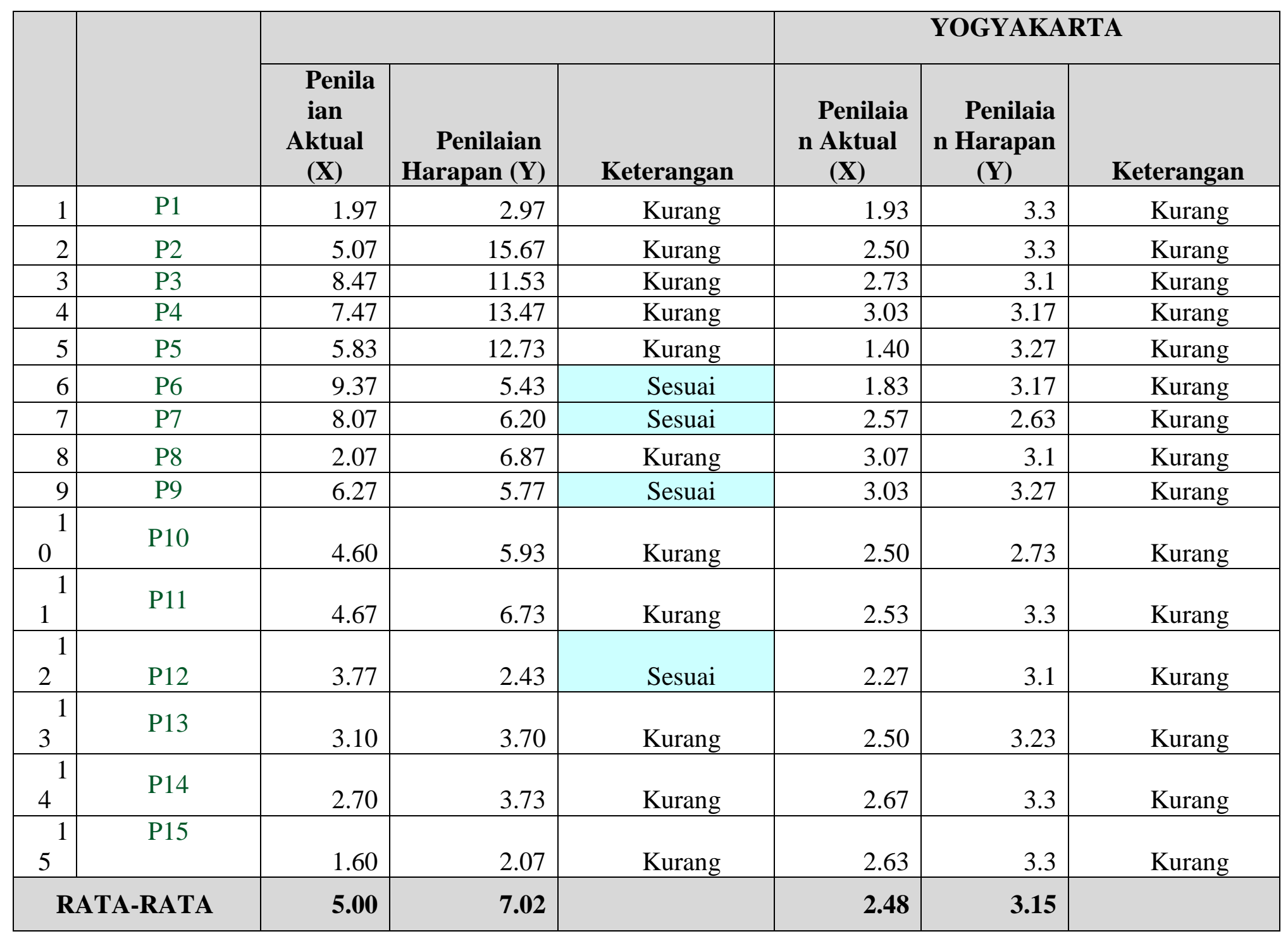




\section{KESIMPULAN DAN SARAN}

Berdasarkan analisis Webqual 4.0 yang dilakukan dari perhitungan rata-rata penilaian aktual dan harapan pengguna layanan website pada masing-masing unsur layanan maupun secara keseluruhan memiliki rata-rata skor aktual lebih kecil daripada rata-rata skor harapan untuk Pemerintahan Provinsi DI Yogyakarta(79.09\%), sedangkan untuk DKI Jakarta $(83.31 \%)$ terdapat 4 unsur layanan website yang memiliki skor rata-rata aktual lebih besar dari harapan, maka dapat disimpulkan bahwa secara umum responden menilai kualitas layanan website resmi milik Pemerintahan Provinsi DI Yogyakarta masih kurang dibandingkan DKI Jakarta.

Untuk meningkatkan kualitas pelayanan website, Pemerintahan Provinsi DI Yogyakarta harus meningkatkan dari segi penggunaan, interaksi dan informasi, sedangkan untuk DKI Jakarta yang harus diperbaiki dari segi penggunaan dan informasi saja.

\section{DAFTAR PUSTAKA}

[1] Jurnal Sistem Informasi (JSI), VOL. 4, NO. 2, Okotober 2012, Halaman 488-50 http://ejournal.unsri.ac.id/index.php/jsi/index :" Evaluasi Kualitas Website Pemerintah Daerah Dengan Menggunakan Webqual (Studi Kasus Pada Kabupaten Ogan Ilir)”

[2] Basri, Setia : uji Validitas dan Realiabilitas dengan SPSS dan Manual [Jum'at/8/4/2015:22.20]

[3] Hendra Rahman, Thesis : Kualitas Pelayanan Website Resmi Milik Pemerintah Kota Surakarta, Digilib.Uns.Ac.Id

[4] Ari-Veikko Anttiroiko and Matti Malka, Enclyclopedia of Digital Government, Volume 3 $(\mathrm{I}-\mathrm{Z})$.

[5] Barnes \& Vidgen: An Integrative Approach to the Assessment of E-Commerce Quality Page 114, AN INTEGRATIVE APPROACH TO THE ASSESSMENT OF ECOMMERCE QUALITY : Journal of Electronic Commerce Research, VOL. 3, NO. 3, 2002

[6] Barnes , S., \& Vidgen, R. (2003), Interactive E-Government: Evaluating the Web Site of the UK Inland Revenue. Journal of Electronic Commerce in Organizations, 2(1), 22pp.

[7] A Quality Model of e-Government Services Based on the ISO/IEC 9126 Standard, Gerald Quirchmayr, Suree Funilkul, Wichian Chutimaskul: Department of Distributed and Multimedia Systems, Faculty of Computer Science, University of Vienna, Liebiggasse 4, A - 1010 Vienna, Austria Email: gerald.quirchmayr@univie.ac.at 
[8] IOSR Journal of Business and Management (IOSR-JBM) e-ISSN: 2278-487X, p-ISSN: 2319-7668. Volume 12, Issue 1 (Jul. - Aug. 2013), PP 92-102 www.iosrjournals.org;Evaluating Perceived Quality of B-School Website s N. Elangovan Assistant Professor, Department of Management Studies, Christ University, Bangalore.

[9] http://www.bps.go.id/linkTabelStatis/view/id/1516 http://nustaffsite.gunadarma.ac.id/blog/bhermana/2007/05/01/mengukur-mutu-website dengan-webqual/

[10] http://www.webqual.co.uk/ WebQual home page.

[11] repository.unhas.ac.id/bitstream/handle/123456789/1819/BAB\%20II.pdf?sequence=9 